\title{
Effectiveness of antibacterial copper additives in silicone implants
}

\author{
Martin Gosau', Ralf Bürgers², Tobias Vollkommer', \\ Thomas Holzmann ${ }^{3}$ and Lukas Prantl ${ }^{4}$
}

\begin{abstract}
Staphylococcus epidermidis plays a major role in capsular contractures of silicone breast implants. This in vitro study evaluates the antibacterial effect of copper on S. epidermidis in silicone implants. Specimens of a silicone material used for breast augmentation ( $\mathrm{Cu} 0$ ) and specimens coated with different copper concentrations (Cul, Cu2) were artificially aged. Surface roughness and surface free energy were assessed. The specimens were incubated in an S. epidermidis suspension. We assessed the quantification and the viability of adhering bacteria by live/dead cell labeling with fluorescence microscopy. Additionally, inhibition of bacterial growth was evaluated by agar diffusion, broth culture, and quantitative culture of surface bacteria. No significant differences in surface roughness and surface free energy were found between $\mathrm{Cu0}$, Cul and Cu2. Aging did not change surface characteristics and the extent of bacterial adhesion. Fluorescence microscopy showed that the quantity of bacteria on $\mathrm{Cu} 0$ was significantly higher than that on $\mathrm{Cul}$ and $\mathrm{Cu} 2$. The ratio of dead to total adhering bacteria was significantly lower on $\mathrm{Cu} 0$ than on $\mathrm{Cul}$ and $\mathrm{Cu} 2$, and tended to be higher for $\mathrm{Cu} 2$ than for $\mathrm{Cul}$. Quantitative culture showed equal trends. Copper additives seem to have anti-adherence and bactericidal effects on $\mathrm{S}$. epidermidis in vitro.
\end{abstract}

\section{Keywords}

Silicone implants, copper additives, Staphyolcoccus epidermidis, implant infection, capsular contracture, antibacterial effect

\section{Introduction}

Bacterial infection is the leading cause of morbidity after breast implant surgery occuring in $2-2.5 \%$ of cosmetic surgical procedures. ${ }^{1,2}$ Two-thirds of infections develop within the acute post-operative period. Some infections, however, may develop years after surgery, resulting either from secondary bacteraemia caused by invasive procedures at other body locations or from an exacerbation of persisting bacteria on the implants., ${ }^{2,3}$ Initial adhesion of specific skin bacteria to silicone breast implant surfaces is assumed to be the major cause of early or late infections and may also be responsible for capsular contractures. ${ }^{4-6}$ Capsular contracture around breast implants is an unpredictable and common complication after breast augmentation and reconstruction with an overall prevalence of up to $17 \% .^{7-12}$ Growing evidence suggests that capsular contracture is associated with subclinical infection of breast implants. The predominantly isolated microorganism from bacteriologic cultures of contracted capsules is Staphylococcus epidermidis. ${ }^{13-17}$ S. epidermidis has been increasingly associated with infections involving prosthetic devices because of its ability to form complex biofilms on their surfaces. ${ }^{18-20}$ Subsequent biofilm growth leads to the development of periprosthetic inflammation and capsular contracture over time. ${ }^{17}$ This process is particularly relevant because biofilmassociated organisms are much more resistant to antimicrobial agents. ${ }^{21,22}$ Additionally, S. epidermidis is often resistant to various antibiotics, such as penicillin, amoxicillin or methicillin. ${ }^{23}$ So far, no effective prophylaxis exists against bacterial colonisation and complex

\footnotetext{
'Department of Cranio-Maxillo-Facial Surgery, University Medical Center Regensburg, Germany

${ }^{2}$ Department of Prosthetic Dentistry, University Medical Center Regensburg, Germany

${ }^{3}$ Institute for Medical Microbiology and Hygiene, University Medical Center Regensburg, Germany

${ }^{4}$ Department of Trauma and Plastic Surgery, University Medical Center Regensburg, Germany

Corresponding author:

Martin Gosau, Department of Cranio-Maxillo-Facial Surgery, University Medical Center, 93042 Regensburg, Germany.

Email: martin.gosau@klinik.uni-regensburg.de
} 
bacterial biofilm formation on silicone implants. However, such prophylaxis may become available through antibacterial surface modifications. ${ }^{13,24}$

In previous studies, copper has proven to be effective in reducing the cell viability of staphylococci ${ }^{25}$ and in addition to the antibacterial effect against $S$. epidermidis in decreasing the amount of adhering bacteria on silicone surfaces. ${ }^{26,27}$ Copper was chosen because comparing growth inhibition tests with tissue cells and bacteria showed copper to be by far the best compromise between antibacterial effectiveness and cytotoxicity. ${ }^{27}$ For confirming the findings by Heidenau and for ascertaining the biocompatibility of our copper-loaded coatings, we conducted resazurin cell viability assay with mammalian cells.

In this subsequent study, we tested the actual copper release from implants and investigated whether a dosedependent antibacterial effect exists upon incubation with different copper concentrations. Additionally, we artificially aged the silicone implants to simulate in vivo conditions. The aging procedure may affect surface parameters, such as surface roughness $\left(\mathrm{R}_{\mathrm{a}}\right)$ or surface free energy (SFE) and therefore microbial adhesion.

In general, the physicochemical surface properties of a biomaterial surface define the potential to adhere microorganisms. In this context, $\mathrm{R}_{\mathrm{a}}$ and hydrophobicity seem to be the main material-linked factors influencing microbial adhesion and biofilm formation on artificial surfaces. ${ }^{28-30}$ When surface roughness and hydrophobicity interact with each other, roughness seems to be the dominant factor in in vitro settings. ${ }^{30-32}$ Amplitude parameters characterise the surface based on the vertical deviations of the roughness profile from the mean line. Rough surfaces enhance bacteria accumulation, whereas smooth materials with reduced surface roughness limit initial biofilm formation in vivo. ${ }^{28-30}$ In this context, a value of $0.2 \mathrm{~nm}$ has been generally accepted as the average roughness threshold below which the amount of bacterial adhesion cannot be reduced any further. ${ }^{33,34} \mathrm{SFE}$ is the interaction between cohesion and adhesion forces, and this interaction determines whether wetting, i.e. the spreading of a liquid over a surface, occurs. Surface energy is usually quantified by means of a contact angle goniometer. On hydrophobic surfaces, the contact angle of a drop of water is larger than on hydrophilic surfaces. Hydrophilicity is indicated by smaller contact angles and higher surface energy. High energy surfaces are known to collect more bacteria. Bacterial strains with high SFE have negative interfacial free energy of adhesion $\left(\Delta \mathrm{F}_{\mathrm{adh}}<0\right)$ at substratum surfaces with high SFE. Therefore, these strains are expected to preferentially adhere to such substrata. ${ }^{35,36}$

After assessing the influence of aging on silicone specimens, we measured the antibacterial effect of copperloaded implant surfaces on S. epidermidis by means of fluorescence microscopy and by colony forming unit tests on agar plates as well as broth culture, and quantitative culture of surface bacteria.

\section{Materials and methods}

\section{Preparation of specimens}

Samples of silicone sheets (measuring $25 \mathrm{~mm}$ in diameter and $0.5 \mathrm{~mm}$ in thickness) were washed in acetone and ethanol. After drying, the silicone surface was modified with carboxy groups via graft polymerisation with $0.4 \mathrm{~mL}$ methyl methacrylate in $100 \mathrm{~mL}$ water started by Fentons reagent (amount per $100 \mathrm{~mL}$ solution: $0.4 \mathrm{~mL}$ hydrogen peroxide, $120 \mathrm{mg}$ Fe-(II)-sulfate, $100 \mathrm{mg}$ Sodium pyrosulfite). The samples were stirred by room temperature for $2 \mathrm{~h}$ and then cleaned in distilled water. The carboxy groups located on the surface were activated at $5^{\circ} \mathrm{C}$ for $30 \mathrm{~min}$ by means of a water-soluble carbodiimide agent $[3 \mathrm{mg}$ N-Cyclohexyl-N'-(2- morpholinoethyl)carbodiimidemethyl-p-toluene sulfonate (CME-CDI) per $1 \mathrm{~mL}$ buffer $(0.1 \mathrm{~mol} / \mathrm{L}$ morpholinoethane sulfonic acid, ph 6 , titrated with sodium hydroxide)]. Then, covalent linking was carried out with deacetylated chitosan, ${ }^{35,36}$ and the samples were cleaned in distilled water. Because the amino groups of the outermost chitosan layer may react with aldehyde groups, a multi-layer on the silicone was generated by alternately dipping the samples in glutaraldehyde solution $(1 \mathrm{wt} \%)$ and in a solution of deacetylated chitosan $(3 \mathrm{wt} \%)$. The dipping procedure was carried out until 20 chitosan layers had been generated on the surface. After this surface modification, the samples were immersed in a copper solution with two different copper concentrations $(\mathrm{Cu}$-acetat in ethanol $32.5 \mathrm{mmol} / \mathrm{L}(\mathrm{Cu} 1)$ and $65 \mathrm{mmol} / \mathrm{L}(\mathrm{Cu} 2)$ ) for $1 \mathrm{~h}$. The purpose of the chitosan layers was to create a surface to integrate the copper ions. The degradation of chitosan is a long-term process and can determine the release rate of copper. A total of 80 specimens were produced, i.e. 40 samples of each material (silicone sheets dipped either in $32.5 \mathrm{mmol} / \mathrm{L} \mathrm{Cu}$-acetat or in $65 \mathrm{mmol} / \mathrm{L} \mathrm{Cu}$ acetat). The silicone sheets with different copper loadings were compared with 40 regular silicone specimens without any chitosan and without any copper.

\section{Measuring of copper release}

Copper release was measured by inductively coupled plasma optical emission spectrometry (ICP-OES). The method of inductively coupled plasma is based on the use of very hot $(10,000 \mathrm{~K})$ argon plasma to excite the optical emission of the elements, which is then analysed. 
ICP-OES-Analysis was done by the FriedrichBaur-Research Institute for Biomaterials, University of Bayreuth, Germany. The copper loaded silicone specimen $(\mathrm{Cu} 1)$ were put in $100 \mathrm{~mL} 0.9 \% \mathrm{NaCl}$ solution as leaching solution at a $\mathrm{pH}$ of 7 and at a temperature of $37^{\circ} \mathrm{C}$ without shaking to mimic physiological conditions for one to eight weeks. Flasks were capped to limit $\mathrm{CO}_{2}$ absorption, since such can influence leaching. For the determination of the copper concentration $5 \mathrm{~mL}$ of the leaching solution were removed every week without adding the taken substrata. The taken aliquots with copper compounds were nebulised into an argon plasma, where all components were vaporised. Copper compounds were dissociated and excited, and then emit radiation of which the intensity was measured at a wavelength of $327.395 \mathrm{~nm}$. The experiment was repeated three times $(n=3$, samples of $\mathrm{Cu} 1)$.

Total possible hydrolysis was calculated as follows: $\mathrm{Cu} 1$ specimens $(n=3)$ were treated with an acetic acid solution (1 M) to wash off all chitosan and copper layers. The amount off dissolved copper in the solution was measured by ICP-OES.

\section{Aging regimes (thermocycling)}

All test and reference materials underwent the same aging regime. Surface roughness, surface free energy, and biofilm testing were determined at the following time points: at baseline, after 7, 14 and 21 days of aging in a thermal cycler (Regensburg Simulator, EGO, Germany). Thermal cycling was done by rinsing the specimens in $0.9 \% \mathrm{NaCl}$ at $5^{\circ} \mathrm{C}$ for one minute and $55^{\circ} \mathrm{C}$ for $1 \mathrm{~min}$ per cycle. There were 30 cycles performed per hour, which equates to 5040 cycles for 7 days, 10,080 cycles for 14 days and 15,120 cycles for 21 days of aging.

\section{Surface roughness $\left(R_{a}\right)$ and surface free energy (SFE/ $\gamma)$}

The arithmetic average of surface roughness $\left(\mathrm{R}_{\mathrm{a}}\right)$ was determined on three spots of the six specimens of each material with a profilometric stylus instrument (Perthometer S6P; Perthen, Goettingen, Germany). The total surface free energy $(\mathrm{SFE} / \gamma)$, its dispersion and polar components were calculated from automated contact angle measurements (OCA 15 plus; Dataphysics Instruments, Filderstadt, Germany). Therefore, three liquids with different surface tensions were used: deionised water, diiodomethane (SigmaAldrich, St. Louis, MO, USA), and ethylene glycol (Merck KgaA, Darmstadt, Germany). Four drops of each liquid $(2 \mu \mathrm{L})$ were examined on five randomly selected specimens of each material. The left and right contact angles of each drop were averaged. SFE was calculated according to the Owens, Wendt, Rabel and Kaelble method. ${ }^{37}$

\section{Cell viability assay}

To evaluate the copper-associated cell toxicity of silicone implants, a resazurin cell viability assay (Biotium, Hayward, CA, USA) was done as described previously ${ }^{38}$ and according to the manufacturer's experimental protocol. Cell viability is detected by measuring the fluorescence or absorbence after conversion of the nonfluorescent resazurin by the reducing environment of growing cells to resurofin, which results in bright red or pink fluorescence.

Briefly, Dulbecco's Modified Eagle Medium (DMEM) (PAA, Pasching, Austria) was conditioned with the silicone material without any copper and coated with either low or high copper concentrations $(\mathrm{Cu} 0, \mathrm{Cu} 1, \mathrm{Cu} 2)$ for $48 \mathrm{~h}$. For cytotoxicity evaluation, primary fibroblasts were plated at a density of 9000 cells per $\mathrm{cm}^{2}$ in 96-well tissue culture plates. Cells were allowed to attach in DMEM with fetal bovine serum in an humified atmosphere at $37^{\circ} \mathrm{C}$ and $5 \%$ $\mathrm{CO}_{2}$ for $12 \mathrm{~h}$, and the medium was changed to the conditioned medium ( $\mathrm{Cu} 0, \mathrm{Cu} 1, \mathrm{Cu} 2)$. Resazurin solution was added to the medium; after cell incubation for 2,10 and $24 \mathrm{~h}$, absorbance was measured at $570 \mathrm{~nm}$ and $600 \mathrm{~nm}$ using a plate reader (E max precision plate reader, Molecular devices, Ismaning, Germany). For background control, the medium without any cells was used. All experiments were conducted in triplicate and repeated in three independent approaches.

\section{Bacteria and biofilm formation}

Staphylococcus epidermidis strain culture (ACAcession: AF270147) was isolated from the skin of one of the authors and identified by partial $16 \mathrm{~s}$ rDNA gene sequencing $\left(\right.$ IDNS $^{\circledR}$ version v3.1.63r14 SmartGene 2005 Molecular Mycobacteriology). After isolation, $S$. epidermidis was proliferated in a BHI-culture medium (Bacto ${ }^{\mathrm{TM}}$ Brain Heart Infusion, BD Becton, Dickinson and Company Sparks, MD, USA). Glycerine was added, and cultures were stored at $-80^{\circ} \mathrm{C}$. The bacterial cultures were defrosted and incubated at $37^{\circ} \mathrm{C}$ overnight before testing. Bacterial cells were then harvested by centrifugation, washed twice in saline $(\mathrm{NaCl} 0.9 \%$ ) and PBS (Phosphate buffered saline) (Sigma-Aldrich, St. Louis, Mo, USA), resuspended in saline, and adjusted by densitometry at $600 \mathrm{~nm}$ to an optical density of 0.9 , which equaled a bacterial concentration of $10^{8} \mathrm{cfu}$ (colony forming units) $/ \mathrm{mL}$. The silicone specimens were put in 24-well plates, $2 \mathrm{~mL}$ of bacterial suspension was added to each well and the plates incubated at $4^{\circ} \mathrm{C}$ for $120 \mathrm{~min}$. 
Bacterial suspension was extracted by suction. Thereafter, the wells were washed twice with $3 \mathrm{~mL}$ of saline to remove non-adhering bacteria.

\section{Enumeration of adhering S. epidermidis and determination of cell viability}

The LIVE/DEAD BacLight bacterial viability kit (Molecular Probes, Eugene, USA) was used to determine the proportion of live and active cells (fluorescent green) and dead and inactive cells (fluorescent red) as described before. ${ }^{39}$ The live or dead stain was prepared by diluting $6 \mu \mathrm{L}$ of staining component A (SYTO 9) and $6 \mu \mathrm{L}$ of staining component $\mathrm{B}$ (propidium iodide) in $5 \mathrm{~mL}$ of distilled water. We added $500 \mu \mathrm{L}$ of the reagent mixture to each well and incubated specimens at room temperature and in darkness for $15 \mathrm{~min}$. Each specimen was carefully positioned on a glass slide covered with component $\mathrm{C}$ (mounting oil) and stored in the dark at $4^{\circ} \mathrm{C}$ until further processing. Fluorescence emission was observed with a fluorescence microscope (Axiovert $200 \mathrm{M}$; Carl Zeiss Microlmaging $\mathrm{GmbH}$, Göttingen, Germany) in combination with the image processing software AxioVision 4.6 (Carl Zeiss Microlmaging $\mathrm{GmbH}$ ). Fluorescent microscopic images of ten randomly selected sites for each specimen were captured with a digital camera (Axiocam MRc5/ MRm; Carl Zeiss Microlmaging $\mathrm{GmbH}$ ) connected to the microscope. Living and dead cells in the same microscopic fields were viewed separately with different fluorescence filter sets (FITC/F41-054 and Alexa594/ F41-027; AHF Analysetechnik, Tübingen, Germany) and digitally combined to one picture. The areas covered by dead cells (fluorescent red) and viable cells (fluorescent green) were calculated as a percentage of specific standard microscopic fields $\left(150 \times 150 \mu \mathrm{m}^{2}\right.$; $n=25$ for each material) with the image analysis software Optimas 6.2 (Meyer Instruments, Houston, USA). Control samples of the silicone material not exposed to bacteria, were tested as a control to ascertain that no autofluorescence of the material disturbs the bacterial count.

\section{Colony forming units test}

Inhibition of bacterial growth was evaluated by agar diffusion, broth culture and quantitative culture of surface bacteria. S. epidermidis was cultured on Columbia Agar containing 5\% sheep blood (Oxoid, Cambridge, UK) for $24 \mathrm{~h}$, harvested, and transferred into $0.9 \%$ saline. The solution was adjusted by densitometry at $600 \mathrm{~nm}$ to an optical density of 0.9 , which equaled a bacterial concentration of $10^{8} \mathrm{cfu} / \mathrm{mL} ; 100 \mu \mathrm{L}$ were plated on Mueller-Hinton-Agar (Oxoid, Cambridge, UK). The silicone specimens were placed on the plates, which were then incubated overnight at $37^{\circ} \mathrm{C}$. Bacterial growth inhibition was evaluated by measuring the zone of inhibition. The test was repeated after preincubating the culture media at $37^{\circ} \mathrm{C}$ for 7 days with the silicone specimens before plating the bacteria.

Broth culture was done by placing the silicone specimens in $1 \mathrm{~mL}$ of BHI culture medium (BD Becton Dickinson, USA) containig a concentration of $10^{8}$ $\mathrm{cfu} / \mathrm{mL}$ of $S$. epidermidis. Bacterial concentrations were determined after $24 \mathrm{~h}$ by densitometry at $600 \mathrm{~nm}$.

For quantitative culture of surface bacteria, the coculture of silicone specimens with $S$. epidermidis was conducted as described above. The silicone specimens were washed in PBS, transferred into $1 \mathrm{~mL}$ of BHI broth, and treated by sonication in an ultrasound cleaner (Bransonic, Branson Corporation, Danburg, USA) for $5 \mathrm{~min}$. We plated $100 \mu \mathrm{L}$ of the BHI broth on Columbia Agar with 5\% sheep blood. Bacterial colonies were enumerated after overnight incubation at $37^{\circ} \mathrm{C}$.

\section{Statistical analysis}

Statistical analysis was done with SPSS 15.0 for Windows (SPSS Corp., Chicago, Ill, USA). Means plus standard deviations were calculated. We used one-way ANOVA to investigate statistical differences and considered a p-value of less than 0.05 statistically significant $(\alpha=0.05)$.

\section{Results}

\section{Copper release of silicone specimen}

Total hydrolysis resulted in the total amount of $2.11 \mathrm{mg} / \mathrm{L}$ copper with a standard deviation of 0.63 , $n=3$. Figure 1 shows the release kinetics of $\mathrm{Cu} 1$ within 8 weeks. We observed continuous copper release over the measured time intervall.

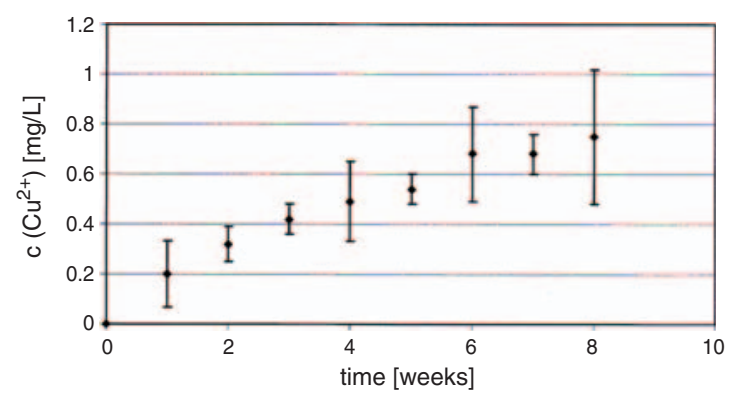

Figure I. Copper release of $\mathrm{Cul}(=32.5 \mathrm{mmol} / \mathrm{L})$ measured by ICP-OES for eight weeks after $\mathrm{Cul}$ had been dipped into sterile saline solution $(n=3)$. 


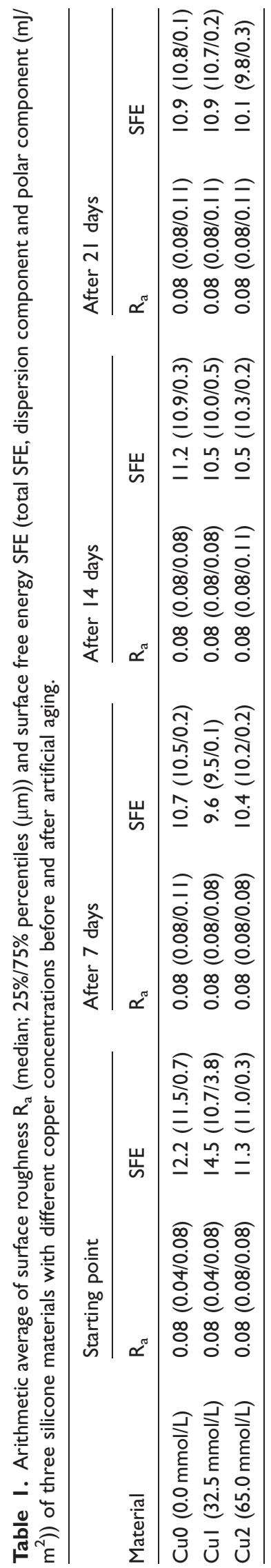

\section{Arithmetic surface roughness $\left(R_{a}\right)$ and total surface free energy (SFE)}

The values from perthometer and goniometer measurements are given in Table 1. One-way ANOVA showed no significant differences in arithmetic surface roughness between the tested silicone specimens with different concentrated copper coatings and differently aged specimens ( $p>0.05$ for all comparisons). Similarly, no significant different SFE values could be found between the three tested silicone specimens with different concentrated copper coatings; neither did aging significantly change SFE ( $p>0.05$ for all comparisons).

\section{Cell viability assay}

Cell viability testing by a resazurin assay did not show any significant cytotoxicity of the silicone specimens to fibroblasts. The different copper coatings did not result in cell toxicity. Figure 2 shows no detectable difference in cell viability in the resazurin assay after 2, 12 and $24 \mathrm{~h}$ with regard to the different copper coatings of the silicone specimens.

\section{Enumeration of adhering S. epidermidis and determination of cell viability}

Examples of fluorescent microscopic images are given in Figure 3. Single cell layers of staphylococcal cells and bacterial clusters in varying concentrations could be found on all fluorometric micrographs. Figure 4 shows the comparative adherence of $S$. epidermidis on

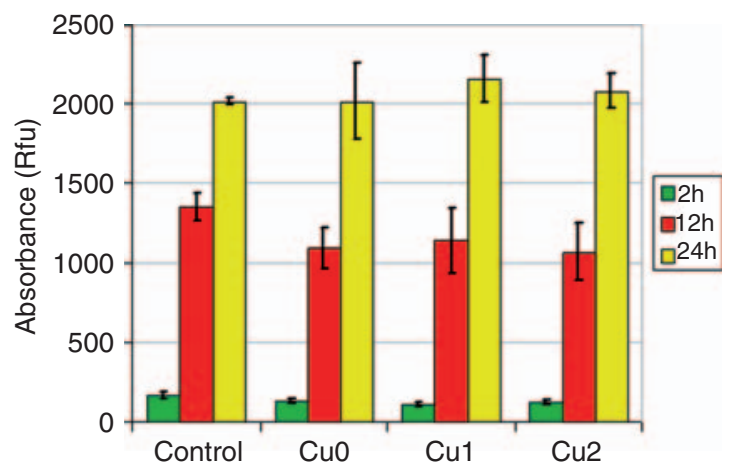

Figure 2. The cell cytotoxicity of copper-coated silicone specimens was determined by resazurin cell viability assay. No significant difference in absorbance could be detected between the control group and the group treated with the differently conditioned media. For background control, all values are corrected by the self-fluorescence of resazurin in the medium. The figure shows median values with standard deviation. $n=3$ for each measurement. $\mathrm{Rfu}=$ relative fluorescence unit. 

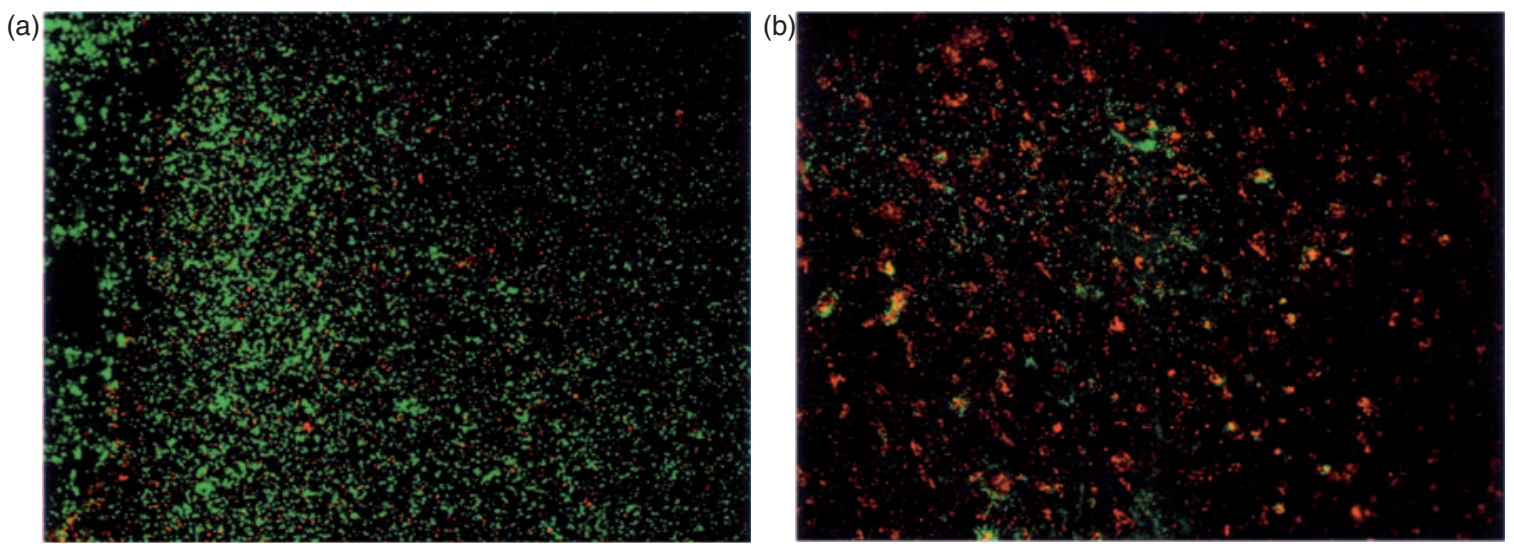

Figure 3. Fluorescence micrographs after live and dead staining. Vital (green) and inactive (red) staphylococci on: (a) pure silicone and (b) silicone with copper additives (Cu2 $=65 \mathrm{mmol} / \mathrm{L}$ ). No artificial aging (original magnification $\times 200$ ). Display window $150 \mu \mathrm{m} \times 150 \mu \mathrm{m}$.

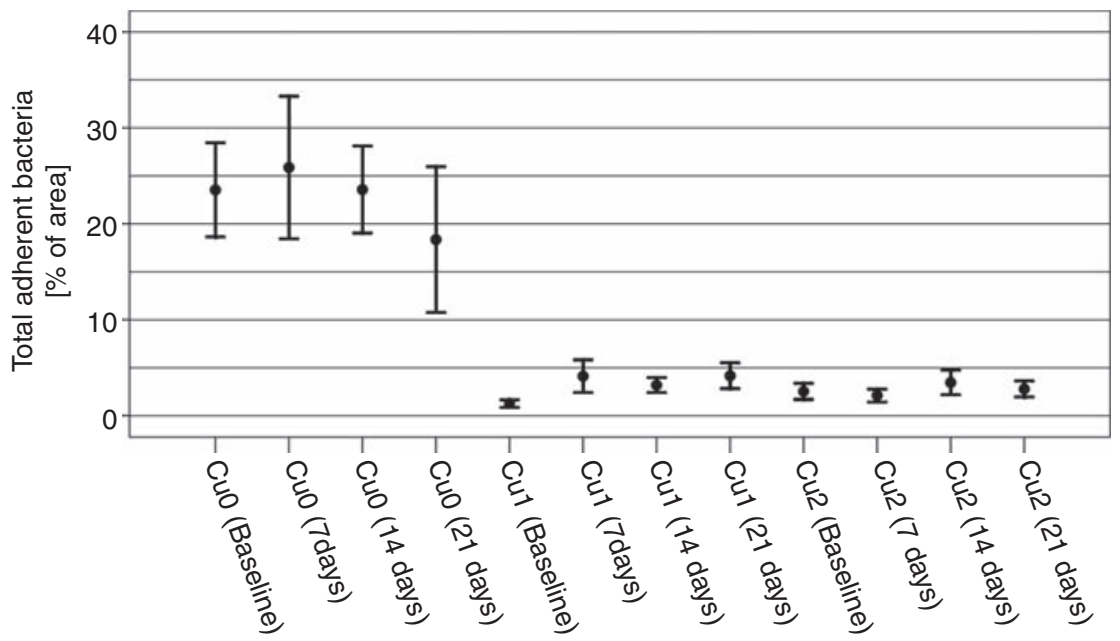

Figure 4. Quantity of adhering S. epidermidis (percentage of area covered with live and dead bacteria; means and standard deviations) on pure silicone $(\mathrm{Cu} 0=0 \mathrm{mmol} / \mathrm{L})$ and silicone with copper additives $(\mathrm{Cul}=32.5 \mathrm{mmol} / \mathrm{L}$ and $\mathrm{Cu} 2=65 \mathrm{mmol} / \mathrm{L})$ before and after artificial aging.

the three tested silicone surfaces shown as the percentage area covered with dead and active bacteria (total amount of adhering bacteria; anti-adhesive effect). The quantity of adhering bacteria on the silicone surfaces without any copper additive was significantly higher independent of the duration of the aging process - than on the surfaces with a copper additive $(p<0.05$ for all comparisons of $\mathrm{Cu} 0$ to $\mathrm{Cu} 1$ and $\mathrm{Cu} 0$ to $\mathrm{Cu} 2$ ). No differences could be found between the total number of cells on the silicone surfaces of $\mathrm{Cu} 1$ and $\mathrm{Cu} 2(p>0.05$ for all comparisons). In contrast, aging did not significantly change the potential to adhere bacteria to either of the three materials tested $(p>0.05$ for all comparisons).

The ratio of dead to total adhering $S$. epidermidis (indicating the bactericidal effect) was significantly lower (by approximately 3 to 4 times) on silicone surfaces without any copper than on materials with copper additives, i.e. a lower amount of inactivated cells was found on copper-free silicone. The ratio of dead to total adhering bacteria by trend was higher for $\mathrm{Cu} 1$ than for $\mathrm{Cu} 2$ but not statistically significant $(p>0.05$ for all comparisons) (Figure 5). Calculations from live and dead staining are given in Table 2.

\section{Culture-based testing of bacterial growth inhibition}

Agar diffusion testing yielded no inhibition of bacterial growth after overnight culture. No difference could be observed between treated and untreated surfaces, neither did the evaluation of growth inhibition after a 7-day preincubation of the silicone specimens show 


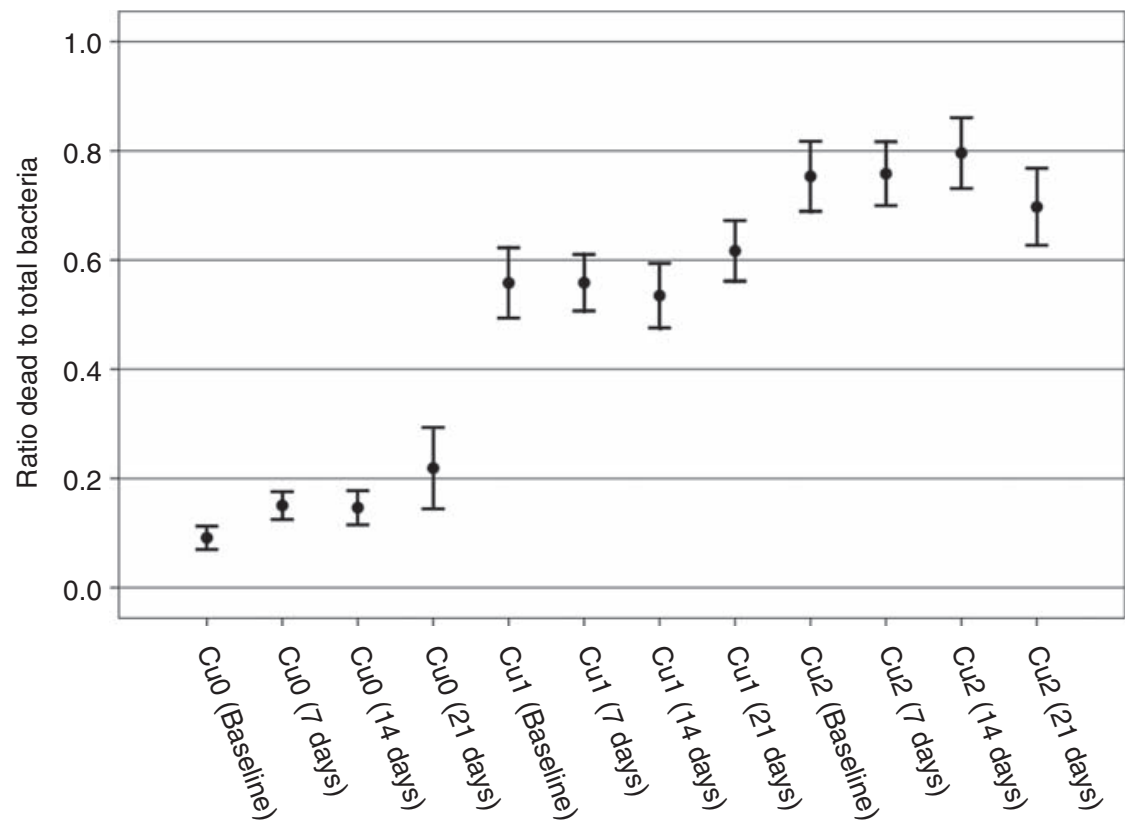

Figure 5. Ratio of dead cells to total bacterial adhesion (means and standard deviations) on pure silicone $(\mathrm{Cu} 0=0 \mathrm{mmol} / \mathrm{L})$ and silicone with copper additives $(\mathrm{Cul}=32.5 \mathrm{mmol} / \mathrm{L}$ and $\mathrm{Cu} 2=65 \mathrm{mmol} / \mathrm{L})$ before and after artificial aging.

any visible zone of inhibition. Broth culture showed no significant differences between copper-coated and uncoated silicone specimens $(p>0.05$ for all comparisons).

Quantitative culture showed a significantly $(p=0.02)$ lower bacterial count for copper-coated surfaces (about $45 \%$ lower bacterial counts) (Figure 6). No significant difference was found between the different aging groups or the different copper concentrations $(p>0.05$ for all comparisons).

\section{Discussion}

Similar to many other polymeric biomaterials, silicone elastomers are prone to biofilm formation. ${ }^{40,41}$ Bacterial adhesion and subsequent biofilm formation are presumed to be responsible for early and late infections of breast and facial silicone implants. ${ }^{6,13}$ Moreover, bacterial colonisation of the implants or implant pockets seems to be responsible for capsular contractures found around breast implants. A strong correlation between the degree of a capsular contracture and the amount of bacterial colonisation could also be shown, and S. epidermidis was the most commonly found bacteria. $6,13,27,42-46$

Based on the results of our previous study evaluating the bactericidal effect of a newly invented copper-loaded coating on silicone breast implants, ${ }^{26}$ we investigated the effect of coatings with different copper concentrations on the adherence and viability of $S$. epidermidis. The surface characteristics of the coated silicone specimens before and after different durations of artificial aging were characterised in defining SFE and $\mathrm{R}_{\mathrm{a}}$. Coherences between changes in surface properties after artificial aging and the in vitro adherence of $S$. epidermidis were evaluated. This study was conducted because reducing bacterial adhesion and biofilm formation on silicone materials with antiadhesive and bactericidal coatings may be essential in preventing implant infections and even capsular contractions around implants. ${ }^{13,42}$

The artificial aging of implants by thermocycling is a common method for simulating in vivo aging of implants. ${ }^{47,48}$ After different aging durations, implants were incubated with a human isolate of $S$. epidermidis to imitate the natural contamination of silicone specimens for our in vitro study, a method that has proven to be valuable before. ${ }^{26,49,50}$

Surprisingly, the findings of this study suggest that artificial aging does not affect $R_{a}$ and SFE of silicone specimens. The lack of change of surface characteristics due to artificial aging is rather striking as, for example, very resistant and hard-wearing dental materials have shown evident changes after the process of artificial aging. ${ }^{47}$ Expected results would have been an increase in $\mathrm{R}_{\mathrm{a}}$ that contributes to higher bacterial colonisation of the aged implants. ${ }^{51,52}$ In our study, $R_{a}$ was determined because high $R_{a}$ values are known to promote bacteria accumulation on exposed surfaces. ${ }^{30}$ The constant surface characteristics with regard to SFE and $R_{a}$ 

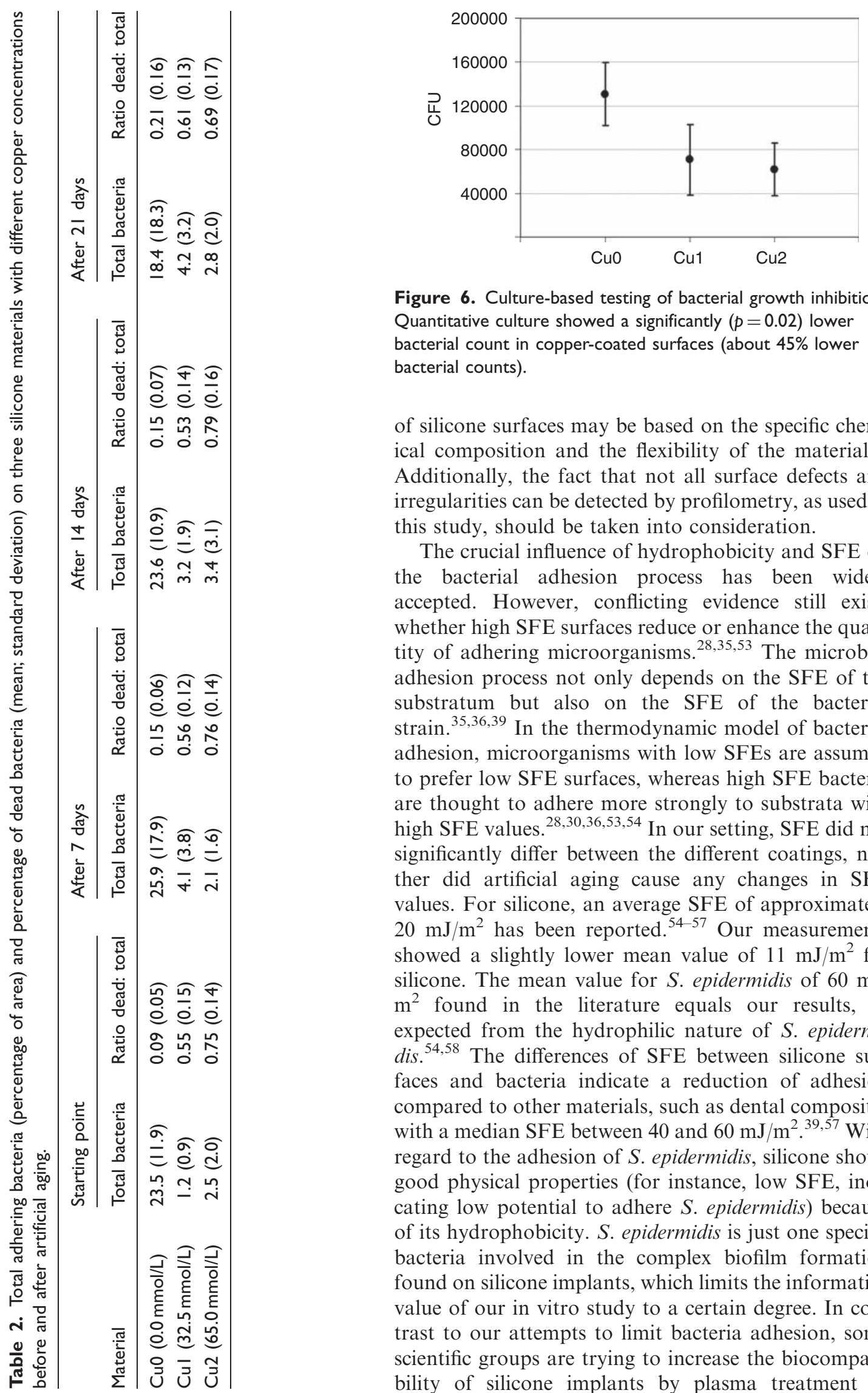

Figure 6. Culture-based testing of bacterial growth inhibition. Quantitative culture showed a significantly $(p=0.02)$ lower bacterial count in copper-coated surfaces (about $45 \%$ lower bacterial counts).

of silicone surfaces may be based on the specific chemical composition and the flexibility of the material. ${ }^{48}$ Additionally, the fact that not all surface defects and irregularities can be detected by profilometry, as used in this study, should be taken into consideration.

The crucial influence of hydrophobicity and SFE on the bacterial adhesion process has been widely accepted. However, conflicting evidence still exists whether high SFE surfaces reduce or enhance the quantity of adhering microorganisms. ${ }^{28,35,53}$ The microbial adhesion process not only depends on the SFE of the substratum but also on the SFE of the bacterial strain. ${ }^{35,36,39}$ In the thermodynamic model of bacterial adhesion, microorganisms with low SFEs are assumed to prefer low SFE surfaces, whereas high SFE bacteria are thought to adhere more strongly to substrata with high SFE values. ${ }^{28,30,36,53,54}$ In our setting, SFE did not significantly differ between the different coatings, neither did artificial aging cause any changes in SFE values. For silicone, an average SFE of approximately $20 \mathrm{~mJ} / \mathrm{m}^{2}$ has been reported. ${ }^{54-57}$ Our measurements showed a slightly lower mean value of $11 \mathrm{~mJ} / \mathrm{m}^{2}$ for silicone. The mean value for S. epidermidis of $60 \mathrm{~mJ} /$ $\mathrm{m}^{2}$ found in the literature equals our results, as expected from the hydrophilic nature of S. epidermidis. ${ }^{54,58}$ The differences of SFE between silicone surfaces and bacteria indicate a reduction of adhesion compared to other materials, such as dental composites with a median SFE between 40 and $60 \mathrm{~mJ} / \mathrm{m}^{2} .^{39,57}$ With regard to the adhesion of $S$. epidermidis, silicone shows good physical properties (for instance, low SFE, indicating low potential to adhere $S$. epidermidis) because of its hydrophobicity. S. epidermidis is just one specific bacteria involved in the complex biofilm formation found on silicone implants, which limits the informative value of our in vitro study to a certain degree. In contrast to our attempts to limit bacteria adhesion, some scientific groups are trying to increase the biocompatibility of silicone implants by plasma treatment to 
enhance cell affinity; this method results in surfaces with higher SFE and $\mathrm{R}_{\mathrm{a}}$ values. ${ }^{55}$

Copper as an antibacterial additive was chosen because copper ions deliver the best compromise between antibacterial effectiveness and cytotoxicity. ${ }^{27}$ Consequently, copper ions proved to most adequately equip implant surfaces with antibacterial properties without significantly decreasing biocompatibility. ${ }^{59-61}$

The resazurin cell viability test did not show any cytotoxicity for coated silicone specimens compared to uncoated silicone specimens. The measurement of the actual copper release from silicone surface showed a continuous release of copper ions over 8 weeks. Of course, a longer observation of copper release would be preferable, because it may be assumed that this release would continue up to week 20 (this assumption is based on the amount of chitosan layers used). The release mechanism could be able to act against early infections as copper release starts at the day of implantation and might act against late infections by continuous copper release.

In this study, the antibacterial and antiadhesive action of copper ions was only shown for initial bacterial adhesion on differently aged materials. That means, that we analysed the beginning of bacterial adhesion process, but this bactericidal effect could as well be shown for aged implants, demonstrating lasting effectivity of the coating. It is possible that the surviving bacteria (green on picture 1(b)) may grow and form a biofilm. We only wanted to detect whether initial biofilm adhesion can be avoided by interfering with the first step of biofilm formation. We believe that it is easier to take action at the very beginning, as complex biofilms are known to withstand the effects of toxic metals better than planktonic cultures of the same species. ${ }^{62}$ In an ongoing study, we will test the effect of copper in a long-term study in an animal model.

It has to be mentioned that even though copper ions are toxic to bacteria, some bacterial species have developed copper resistance mechanisms. Acquired bacterial copper resistance has been described for both Grampositive and Gram-negative organisms ${ }^{62,63}$ for example, Enterococcus faecium and E. faecalis isolated from humans. ${ }^{63}$

The exact detection of adhering staphylococci and the necessary differentiation between dead and viable cells is given by the applied fluorescent staining technique. ${ }^{64}$ The total amount of bacteria detected by BacLight staining showed significantly more adherent bacteria on the reference material than on the copperloaded silicone specimen without any significant difference between the differently coated specimens. Additionally, significantly more membrane-damaged (dead) cells were found on copper-loaded specimens than on the reference silicone. Even though no significant bactericidal effect could be shown for higher copper concentrations, a tendency was found yielding concentration-dependent bactericidal effects of higher copper concentrations.

We were only partly able to confirm the results obtained by live/dead-staining and fluorescence microscopy with culture-based testing of bacterial growth inhibition. As expected, the released amount of copper was not high enough to result in a zone of inhibition on an agar plate or an extensive killing of planctonic bacteria that could have been detected by conventional culture methods. The applied methods of blasting the adhering bacteria from the surface with ultrasound could only show a $45 \%$ reduction in bacterial counts between coated and uncoated surfaces. Therefore, we applied fluorescence microscopy for directly monitoring bactericidal and anti-adhesive effects of copper-loaded substrata on the surface of the material. $^{31,39}$

Nevertheless, this study confirmed our previous findings, ${ }^{26}$ i.e. no concentration-dependent effects could be found. Artificial aging did not change surface properties, and copper additives showed lasting bactericidal and anti-adhesive effects. This newly invented coating of silicone specimens is able to release copper ions over an extended period of time, enabling a lasting bactericidal effect on S. epidermidis.

\section{Conclusion}

Based on the findings of our previous research, we were able to show in this study that the newly invented copper-coating of silicone breast implants has positive anti-adhesive and antibacterial effects against $S$. epidermidis. Additionally, copper ions were released over time, proven by persistent anti-adhesive and antibacterial properties after artificial aging. Consequently, copper-coated silicone may reduce early and late infections of breast implants and may thus also lower the number of capsular contractions.

\section{Funding}

This research received no specific grant from any funding agency in the public, commercial, or not-for-profit sectors.

\section{Acknowledgments}

We thank the Friedrich-Baur-Research Institute for Biomaterials, University of Bayreuth, Germany, for their excellent work of modifing silicone sheets with copper ions for antibacterial effect. We also thank the Mentor ${ }^{\circledR}$ Cooperation, Irving Texas, USA, for their generous supply of silicone material. 


\section{References}

1. Feldman EM, Kontoyiannis DP, Sharabi SE, et al. Breast implant infections: is cefazolin enough? Plast Reconstr Surg 2010; 26: 779-785.

2. Pittet B, Montandon D and Pittet D. Infection in breast implants. Lancet Infect Dis 2005; 5: 94-106.

3. Darouiche RO. Treatment of infections associated with surgical implants. $N$ Engl J Med 2004; 350: 1422-1429.

4. Handel N, Cordray T, Gutierrez J, et al. A long-term study of outcomes, complications, and patient satisfaction with breast implants. Plast Reconstr Surg 2006; 117: 757-767.

5. Gubisch W and Kotzur A. Our experience with silicone in rhinomentoplasty. Aesthetic Plast Surg 1998; 22: 237-244.

6. Schreml S, Heine N, Eisenmann-Klein M, et al. Bacterial colonization is of major relevance for high grade capsular contracture after augmentation mammaplasty. Ann Plast Surg 2007; 59: 126-130.

7. Alfano C, Mazzocchi M and Scuderi N. Mammary compliance: an objective measurement of capsular contracture. Aesthetic Plast Surg 2004; 28: 75-79.

8. Benediktsson $\mathrm{K}$ and Perbeck L. Capsular contracture around saline-filled and textured subcutaneouslyplaced implants in irradiated and nonirradiated breast cancer patients: Five years of monitoring of a prospective trial. J Plast Reconstr Aesthet Surg 2006; 59: 27-34.

9. Gabriel SE, Woods JE, O'Fallon WM, et al. Complications leading to surgery after breast implantation. N Engl J Med 1997; 336: 677-682.

10. Gylbert L, Asplund O and Jurell G. Capsular contracture after breast reconstruction with silicone and saline-filled implants: a 6-year follow- up. Plast Reconstr Surg 1990; 86: 809-811.

11. Handel N, Jensen JA, Black Q, et al. The fate of breast implants: a critical analysis of complications and outcomes. Plast Reconstr Surg 1995; 96: 1521-1533.

12. Henriksen TF, Fryzek JP, Hölmich LR, et al. Surgical intervention and capsular contracture after breast augmentation: a prospective study of risk factors. Ann Plast Surg 2005; 54: 343-351.

13. Embrey M, Adams EE, Cunningham B, et al. A review of the literature on the aetiology of capsular contracture and a pilot study to determine the outcome of capsular contracture interventions. Aesthetic Plast Surg 1999; 23: 197-206.

14. Jung DH, Kim BR, Choi JY, et al. Gross and pathologic analysis of long-term silicone implants inserted into the human body for augmentation rhinoplasty: 221 revision cases. Plast Reconstr Surg 2007; 120: 1997-2003.

15. Kim J, Pitts B, Stewart PS, et al. Comparison of the antimicrobial effects of chlorine, silver ion, and tobramycin on biofilm. Antimicrob Agents Chemother 2008; 52: 1446-1453.

16. Pajkos A, Deva AK, Vickery K, et al. Detection of subclinical infection in significant breast implant capsules. Plast Reconstr Surg 2003; 111: 1605-1611.
17. Tamboto H, Vickery K and Deva AK. Subclinical (biofilm) infection causes capsular contracture in a porcine model following augmentation mammaplasty. Plast Reconstr Surg 2010; 126: 835-842.

18. Donlan RM. Biofilms and device-associated infections. Emerg Infect Dis 2001; 7: 277-281.

19. O'Gara JP and Humphreys H. Staphylococcus epidermidis biofilms: importance and implications. $J$ Med Microbiol 2001; 50: 582-587.

20. Vinh DC and Embil JM. Device-related infections: a review. J Long Term Eff Med Implants 2005; 15: 467-488.

21. Donlan RM. Biofilm formation: a clinically relevant microbiological process. Clin Infect Dis 2001; 33: 1387-1392.

22. Gilbert P, Das JR, Jones MV, et al. Assessment of resistance towards biocides following the attachment of microorganisms to, and growth on, surfaces. J Appl Microbiol 2001; 91: 248-254.

23. Kiedrowski MR and Horswill AR. New approaches for treating staphylococcal biofilm infections. Ann N Y Acad Sci 2011; 1241: 104-121.

24. van Heerden J, Turner M, Hoffmann D, et al. Antimicrobial coating agents: can biofilm formation on a breast implant be prevented? J Plast Reconstr Aesthet Surg 2009; 62: 610-617.

25. Neel EA, Ahmed I, Pratten J, et al. Characterisation of antibacterial copper releasing degradable phosphate glass fibres. Biomaterials 2005; 26: 2247-2254.

26. Gosau M, Prantl L, Feldmann M, et al. The effects of copper additives on the quantity and cell viability of adherent Staphylococcus epidermidis in silicone implants. Biofouling 2010; 26: 359-365.

27. Heidenau F, Mittelmeier W, Detsch R, et al. A novel antibacterial titania coating: metal ion toxicity and in vitro surface colonization. J Mater Sci Mater Med 2005; 16: 883-888.

28. An YH and Friedman RJ. Concise review of mechanisms of bacterial adhesion to biomaterial surfaces. J Biomed Mater Res 1998; 43: 338-348.

29. Rasperini G, Maglione M, Cocconcelli P, et al. In vivo early plaque formation on pure titanium and ceramic abutments: a comparative microbiological and SEM analysis. Clin Oral Implants Res 1998; 9: 357-364.

30. Teughels W, Van AN, Sliepen I, et al. Effect of material characteristics and/or surface topography on biofilm development. Clin Oral Implants Res 2006; 17: 68-81.

31. Bürgers R, Gerlach $T$, Hahnel $S$, et al. In vivo and in vitro biofilm formation on two different titanium implant surfaces. Clin Oral Implants Res 2010; 21: 156-164.

32. Quirynen M, Bollen CM, Papaioannou W, et al. The influence of titanium abutment surface roughness on plaque accumulation and gingivitis: short-term observations. Int J Oral Maxillofac Implants 1996; 11: 169-178.

33. Bollen CM, Lambrechts P and Quirynen M. Comparison of surface roughness of oral hard materials to the threshold surface roughness for bacterial plaque retention: a review of the literature. Dent Mater 1997; 13: 258-269. 
34. Elter C, Heuer W, Demling A, et al. Supra- and subgingival biofilm formation on implant abutments with different surface characteristics. Int $J$ Oral Maxillofac Implants 2008; 23: 327-334.

35. Pratt-Terpstra IH, Weerkamp AH and Busscher HJ. Microbial factors in a thermodynamic approach of oral streptococcal adhesion to solid substrata. $J$ Colloid Interface Sci 1988; 129: 568-574.

36. Weerkamp AH, van der Mei HC and Busscher HJ. The surface free energy of oral streptococci after being coated with saliva and its relation to adhesion in the mouth. J Dent Res 1985; 64: 1204-1210.

37. Owens DK and Wendt RC. Estimation of the surface free energy of polymers. J Appl Polym Sci 1969; 13: 1741-1747.

38. Nociari MM, Shalev A, Benias P, et al. A novel one-step, highly sensitive fluorometric assay to evaluate cellmediated cytotoxicity. J Immunol Methods 1998; 213: 157-167.

39. Bürgers R, Eidt A, Frankenberger R, et al. The antiadherence activity and bactericidal effect of microparticulate silver additives in composite resin materials. Arch Oral Biol 2009; 54: 595-601.

40. McBride MC, Malcolm RK, Woolfson AD, et al. Persistence of antimicrobial activity through sustained release of triclosan from pegylated silicone elastomers. Biomaterials 2009; 30: 6739-6747.

41. Stickler DJ and McLean RJC. Biomaterials associated infections: the scale of the problem. Cell Mater 1995; 5: 167-182.

42. Hoffmann B, Volkmer E, Kokott A, et al. A new biodegradable bone wax substitute with the potential to be used as a bone filling material. J Mater Chem 2007; 17 : 4028-4033.

43. Dobke MK, Svahn JK, Vastine VL, et al. Characterization of microbial presence at the surface of silicone mammary implants. Ann Plast Surg 1995; 34: 563-569.

44. Freedman AM and Jackson IT. Infections in breast implants. Infect Dis Clin North Am 1989; 3: 275-287.

45. Siggelkow W, Faridi A, Spiritus K, et al. Histological analysis of silicone breast implant capsules and correlation with capsular contracture. Biomaterials 2003; 24 : 1101-1109.

46. Tang H, Cao T, Wang A, et al. Effect of surface modification of silicone on Staphylococcus epidermidis adhesion and colonization. J Biomed Mater Res A 2007; 80: 885-894.

47. Bürgers R, Cariaga T, Müller R, et al. Effects of aging on surface properties and adhesion of Streptococcus mutans on various fissure sealants. Clin Oral Invest 2009; 13: 419-426.

48. Hahnel S, Rosentritt M, Burgers R, et al. Surface properties and in vitro Streptococcus mutans adhesion to dental resin polymers. J Mater Sci Mater Med 2008; 19: 2619-2627.

49. Broekhuizen CA, de Boer L, Schipper K, et al. Periimplant tissue is an important niche for Staphylococcus epidermidis in experimental biomaterial-associated infection in mice. Infect Immun 2007; 75: 1129-1136.
50. Kodjikian L, Casoli-Bergeron E, Malet F, et al. Bacterial adhesion to conventional hydrogel and new siliconehydrogel contact lens materials. Graefes Arch Clin Exp Ophthalmol 2008; 246: 267-273.

51. Yip HK, To WM and Smales RJ. Effects of artificial saliva and APF gel on the surface roughness of newer glass ionomer cements. Oper Dent 2004; 29: 661-668.

52. Zanin FR, Garcia LF, Casemiro LA, et al. Effect of artificial accelerated aging on color stability and surface roughness of indirect composites. Eur J Prosthodont Restor Dent 2008; 16: 10-14.

53. Hahnel S, Rosentritt M, Handel G, et al. In vitro evaluation of artificial ageing on surface properties and early Candida albicans adhesion to prosthetic resins. J Mater Sci Mater Med 2009; 20: 249-255.

54. Quirynen M and Bollen CM. The influence of surface roughness and surface-free energy on supra- and subgingival plaque formation in man. A review of the literature. J Clin Periodontol 1995; 22: 1-14.

55. Morra M and Cassinelli C. Bacterial adhesion to polymer surfaces: a critical review of surface thermodynamic approaches. J Biomater Sci Polym Ed 1997; 9: $55-74$.

56. Hauser J, Zietlow J, Köller M, et al. Enhanced cell adhesion to silicone implant material through plasma surface modification. J Mater Sci Mater Med 2009; 20: 2541-2548.

57. Hulterström AK, Berglund A and Ruyter IE. Wettability, water sorption and water solubility of seven silicone elastomers used for maxillofacial prostheses. $J$ Mater Sci Mater Med 2008; 19: 225-231.

58. Pereni CI, Zhao Q, Liu Y, et al. Surface free energy effect on bacterial retention. Colloids Surf B Biointerfaces 2006; 48: $143-147$.

59. Barton AJ, Sagers RD and Pitt WG. Measurement of bacterial growth rates on polymers. J Biomed Mater Res 1996; 32: 271-278.

60. Macadam SA, Clugston PA and Germann ET. Retrospective case review of capsular contracture after two-stage breast reconstruction: is colonization of the tissue expander pocket associated with subsequent implant capsular contracture? Ann Plast Surg 2004; 53: 420-424.

61. Nan L, Liu Y, Lü M, et al. Study on antibacterial mechanism of copper-bearing austenitic antibacterial stainless steel by atomic force microscopy. J Mater Sci Mater Med 2008; 19: 3057-3062.

62. Hasman $\mathrm{H}$ and Aarestrup FM. tcrB, a gene conferring transferable copper resistance in Enterococcus faecium: occurrence, transferability, and inkage to macrolide and glycopeptide resistance. Antimicrob Agents Chemother 2002; 46: 1410-1416.

63. Hasman H, Kempf I, Chidaine B, et al. Copper resistance in Enterococcus faecium, mediated by the tcrB gene, is selected by supplementation of pig feed with copper sulfate. Appl Environ Microbiol 2006; 72: 5784-5789.

64. Decker EM. The ability of direct fluorescence-based, two-colour assays to detect different physiological states 
of oral streptococci. Lett Appl Microbiol 2001; 33: 188-192.

65. Baumann H and Kokott A. Surface modification of the polymers present in a polysulfone hollow fiber hemodialyser by covalent binding of heparin or endothelial cell surface heparan sulfate: flow characteristics and platelet adhesion. J Biomat Sci Polymer Edn 2000; 11: 245-272.

66. Booth SC, Workentine ML, Wen J, et al. Differences in metabolism between the biofilm and planktonic response to metal stress. J Proteome Res 2011; 10: 3190-3199. 